\title{
Urban Planning Regulations for Tourism in the Context of Overtourism. Applications in Historic Centres
}

\author{
Manuel de la Calle-Vaquero*(D), María García-Hernández (D) and Sofía Mendoza de Miguel (D) \\ Department of Geography, Universidad Complutense de Madrid, 28040 Madrid, Spain; \\ mgarciah@ucm.es (M.G.-H.); smendo01@ucm.es (S.M.d.M.) \\ * Correspondence: mcalleva@ucm.es
}

check for updates

Citation: Calle-Vaquero, M.d.l.;

García-Hernández, M.; Mendoza de

Miguel, S. Urban Planning

Regulations for Tourism in the

Context of Overtourism. Applications

in Historic Centres. Sustainability

2021, 13, 70. https://doi.org/

$10.3390 /$ su13010070

Received: 29 November 2020

Accepted: 21 December 2020

Published: 23 December 2020

Publisher's Note: MDPI stays neutral with regard to jurisdictional claims in published maps and institutional affiliations.

Copyright: () 2020 by the authors. Licensee MDPI, Basel, Switzerland. This article is an open access article distributed under the terms and conditions of the Creative Commons Attribution (CC BY) license (https: / / creativecommons.org/ licenses/by/4.0/).

\begin{abstract}
The rapid growth in urban tourism has brought great pressure to the historic centres, intensifying the negative externalities that threaten their protection and proper functioning. The aim of this article is to analyse the use of urban planning regulations as an instrument for containing tourism activity in situations of overtourism. A two-stage methodological approach is employed: Firstly, a review of the local governments' response to the effects of tourism growth and the possibilities of local control in 46 Spanish cities is presented; secondly, a comparative analysis of the stricter short-term rentals regulations adopted by those cities is carried out. The common basis of the adopted regulations is the control of tourist use of an entire dwelling. Of the cities analysed, Barcelona has the most restrictive regulation, while in all the other cities, regulation is less restrictive and depends on the type of accommodation in question and/or the conditions imposed on issuing new licences. The results demonstrate the difficulties entailed in the process of formulating and applying regulations and reveal imbalances between the economic and urban planning visions, and between the rapid change in tourism and the much slower response capacity of governments.
\end{abstract}

Keywords: urban planning; overtourism; short-term rentals; historic centres; Spanish cities

\section{Introduction}

In the years leading up to the outbreak of the COVID-19 pandemic in 2020, many cities experienced rapid growth in tourism. In parallel, the proliferation of short-term rentals (STRs) has driven a surge in visitor flows and has exerted a disruptive effect on the tourism industry and destinations alike. The sharp increase in STRs has particularly affected urban centres, the areas with the highest concentration of tourist attractions. In many European cities, such centres are also totally or partially historic sites subject to heritage protection in accordance with the legislation of each country, and in some cases are also included in the UNESCO World Heritage list.

Although increased tourism activity generates benefits for the city as a whole, greater tourism pressure in central areas has also triggered the emergence or intensification of negative externalities that threaten their protection and proper functioning. These include a decline in the quality of life [1-4]; the loss of tourist appeal [5]; an increase in the cost of housing [6-11]; environmental pollution [12] that affects water quality [13] and air quality [14]; noise pollution [15], which particularly affects residents' everyday lives; overcrowding in public spaces [16] and congested infrastructures and services [17,18] and traffic [19]; an increase in crime [5,20]; the loss of cultural identity [21,22]; and an increase in the cost of living $[23,24]$. This long list of problems is encapsulated in concepts such as "touristification" [25-30], "tourism gentrification" [30-35] and more recently, "overtourism" [16,20,36-40]. All three terms, which first appeared in the academic literature but now appear frequently in the mass media, refer to the same kind of problem. However, each one is associated with different interpretations of the causes and meanings associated with underlying urban processes. 
Urban policies on tourism are being adapted in their entirety or in part to this new situation, and many cities have begun to adopt strategies to cope with situations and processes of overtourism. From a critical perspective, Milano [41] has divided these strategies into five groups (5D) according to their main goal: Deseasonalisation, decongestion, decentralisation, diversification, and deluxe tourism. Abbasian, Onn, and Arnautovic [42] have differentiated between infrastructure-oriented, tourist-oriented, local authority-oriented, and tour operator-oriented or similar solutions. Meanwhile, Eckert, Zacher, Pechlaner, Namberger, and Schmude [43] have again divided such measures into five groups: Understanding the role of tourism, spatial and seasonal distribution, promoting tourism acceptance, restrictions and monitoring, and smart destination development. Lastly, Veríssimo, Moraes, Breda, Guizi, and Costa [44] have identified six types of strategy: Those focused on infrastructures and decentralisation, those that seek local involvement and collaboration, those oriented towards planning and regulation, those focused on promoting smart tourism, those oriented towards degrowth and segmentation, and those that seek to facilitate tourist-resident interaction. Among other goals, all these strategies are aimed at containing tourism activity, where containment implies reducing pressure on central areas while simultaneously promoting greater tourism activity in peripheral neighbourhoods. Achieving this objective entails adopting a variety of measures. Mendoza et al. [45] classified these according to the corresponding sector in local government, for example, marketing policies (in this case aimed at attracting visitors to lesser-known places), transport policies (related to reducing arrivals at the destination and/or its central areas), smart tourism destinations (for the internal management of tourist flows), and so on. Among these policies is urban planning.

The present article focuses on the use of urban planning regulations as an instrument for containing tourism activity in situations of overtourism and discusses Spanish cities that have formulated this type of regulation mainly in the period 2015-2019. Although urban policies extend beyond urban planning [46], local governments' capacity to determine land uses endows them with a very powerful tool for regulating new tourism activities. The study objectives were therefore as follows: (1) To determine the extent to which Spanish cities regulate tourism use, identifying each city's position in relation to regulation; (2) to identify and analyse specific regulatory instruments, rationales and mechanisms; and (3) to contextualise this regulation in an international framework, with reference to comparable studies. The article is divided into five sections reflecting these objectives. After the introduction (first section), we present a review of the literature on urban planning and tourism, focusing in particular on recent studies on the regulation of STRs (second section). We then discuss the general situation in Spanish cities and describe our empirical study methods (third section). Next, we present our main results, identifying the positions of local governments in relation to urban regulations and detailing current regulations (fourth section). In the fifth and final section, we discuss these results and draw several conclusions of varying scope.

The present study represents an advance in knowledge of overtourism management at an urban level. Although numerous studies on overtourism worldwide and in Spain have been published in the past five years, few have examined urban planning regulations from a comparative perspective. Case studies in particular have proliferated and reference to the exceptional case of Barcelona is a constant in the literature and the media alike. In contrast, our aim was to interpret the general situation in Spain based on a broad sample of 46 cities and to conduct a comparison with the urban regulation of tourism in other countries. Our conclusions indicate the difficulties involved as regards both formulating and applying the regulations and the disparity between the dizzying, disruptive speed of change in tourism and the much slower capacity for response of governments. This study also opens up new fields of research in an agenda marked by the uncertainty of an anxiously awaited post-pandemic recovery. 


\section{Urban Planning and Tourism: State of the Question}

All urban policies influence a city's development as a tourist destination. However, among these policies, urban planning is of particular importance. Although its scope, content, and even name varies from country to country, urban planning refers to the physical planning of a city. Such planning includes various plans that operate at different scales and are generally developed and implemented by local governments. The more general plans establish the city model and the mechanisms to achieve this model, which include the design of interventions on urban infrastructure and a series of regulations establishing the legal framework. Zoning is a widespread technique, and the management of planning provisions is one of the central activities of local governments.

Although urban planning is crucial in shaping a place as a tourist destination, urban planners have been reluctant to systematically reflect on tourism. This lack of reflection has hindered the integration of tourism into urban planning based on the regulated allocation of land use. Several difficulties arise as a result, as was indicated by Dredge and Moore back in 1992 [47]. First, there is a lack of definition of tourism, or at least urban planners have failed to define it as a clearly identifiable sector, hindering access to relevant and consistent data. The data available are always insufficient. Second, urban planners-whose actions are geared towards public service-find it difficult to understand a market where tourism companies primarily seek to maximise profits. Furthermore, the tourism sector is highly fragmented, rendering it difficult to represent all interests in formal participation procedures. Consequently, there are major discrepancies between the idea of city image from the perspective of urban planning and that of tourism marketing. These difficulties persist despite efforts to achieve a better understanding of the connections between tourism planning and urban planning [48] and to conceptualise the central geographical elements of a destination in order to assist the land use planning process [49].

Tourism and urban planning converge most when the creation of a destination involves a general process of tourism urbanisation, as in the case of sun and beach destinations where land use plans are applied. Site planning delineates the precise configuration of public and private facilities, followed by architectural, landscaping. and engineering design [50]. In contrast, tourism has only occasionally and very recently been considered in planning instruments for urban destinations. There are several reasons for this. On the one hand, the phenomenon of tourism only entered the local political agenda a few decades ago, even though some cities have been receiving visitors since the inception of modern tourism. On the other hand, tourism in urban destinations does not involve creating new spaces as much as refurbishing existing ones. Above all, tourism implies catering for a new type of user or consumer-the visitor-in areas already used by residents, other inhabitants of the urban agglomeration, and commuters from further afield. These difficulties in approach are also reflected in the relative paucity of literature in this field, at least in comparison with studies of this subject in sun and beach destinations. In this respect, Larsen [51] has noted that questions related to "urban contexts" are relatively little discussed in tourism research, while tourism attracts even less research attention in urban studies. However, some studies are beginning to be published. Of note is a special issue edited by Shoval [52] examining the interrelationship between urban planning and tourism consumption in European cities. Studies of Dubrovnik [53] and Budapest [54] have also contributed interesting reflections on urban planning and tourism development, while a study of Copenhagen has linked urban planning and cycle tourism [55]. In addition, planning has been related to guidelines on tourist accommodation in studies of cities such as Lisbon [56] and Prague [57].

References to tourism can also be found in studies on urban heritage, regeneration, mega-projects, mobility, land use regulation, and other matters related to the physical planning of a city. In general, such studies note the potential effects of these actions on urban tourism development. Achieving these effects may be an explicit goal of planning, but sometimes it is merely an implicit aim. At other times, the effects are unintended and even antithetical to the overall intention of the action. In general, urban planners have assumed that the effects are positive: However, critical perspectives have always 
maintained a negative view of tourism, and this has become more widespread as situations and processes of overtourism have arisen. Given that urban planning is the primary instrument for regulating land uses, part of the debate has focused on the regulation of purely tourism uses, such as tourist accommodation and especially STRs.

This type of rental accommodation is very common in a large number of tourist destinations, especially sun and beach destinations. While not a new phenomenon in urban destinations, it has grown exponentially following the advent of large platform companies such as Airbnb (platform-mediated STRs). The expansion of STRs in large cities has had a disruptive effect at various levels [58,59]. First, this new business model poses a major challenge to the conventional accommodation market, primarily the hotel sector. Second, at the destination level, it has generated several negative externalities, placing greater pressure on the housing market and transforming residential neighbourhoods. As a result of STRs, touristification is now permeating central districts that were not previously on the "beaten track". Consequently, numerous local governments have begun to adopt regulations governing STRs to reconcile the interests of property owners and residents in the most severely affected neighbourhoods.

A plethora of academic studies from a range of disciplinary fields have examined the expansion and effects of STRs in cities. Although taking a broader approach, much of the research on Airbnb and the sharing economy refers to regulations adopted at the urban level. In a review of digital platforms and cities, Artioli [60] identified regulation and governance as being among the five major topics of urban research. Such studies are generally based on an analysis of local government policy documents but may also refer to reports by the main stakeholders or interviews conducted with politicians and specialist staff and may frequently cite news items in the mass media. Among other aspects, they have described the rationale for the regulations, their scope, their content in the form of regulatory measures, and their effects. Some studies have quantified the existing supply of STRs, obtained by scraping websites such as Inside Airbnb and Airdna, while others have focused more on the legislative aspects, examining the urban regulations. In general, these latter comprise case studies of a single city over a specific period of time. For example, Lambea [61] has analysed the situation in Barcelona, paying particular attention to urban planning measures to mitigate the negative impact of the sharp increase in private dwellings being transformed into tourist accommodation, while Schäfer and Braun [62] have quantified the supply of housing in Berlin subject to misuse as defined in the city's Zweckentfremdungsverbot (misuse prohibition law). Using the case of London, Ferreri and Sanyal [63] have demonstrated that sharing or platform economy companies are involved in encouraging governments to change existing regulations, in this case by deregulating short-term letting. This has important implications for planning enforcement. Meanwhile, Van Holm [64] has assessed the effects of the regulation adopted in New Orleans on accommodation advertised on Airbnb and its geographical distribution, as this regulation affects different areas of the city differently.

Although fewer comparative studies of cities have been conducted, they are becoming increasingly important. From a legal perspective, Palombo [65] has compared the regulations on zoning, taxation, insurance, and liability issues adopted in New York and San Francisco, defining their positions as "conservative" and "liberal", respectively. Meanwhile, Cassell and Deutsch [66] have analysed the regulation of STRs in the 10 most populated cities in Germany, identifying three possible local government positions regarding the phenomenon of STRs: Laissez-faire, prohibition, and allowing Airbnb but only under specific conditions.

Studies comparing cities in different countries encounter greater difficulties. Dredge et al. [67] have analysed the regulatory responses adopted in the cities of Amsterdam, Barcelona, Berlin, and Paris. In addition to these cities, Hajibaba and Dolnicar [68] included London, New York, Reykjavik, San Francisco, and Tokyo in their analysis. In all these cities, there is a clear distinction between 'hosted rentals' (the short-term rental of space within the host's primary residence when the host is present) and 'unhosted rentals' 
(short-term rental of primary residences when hosts are not present). However, there are significant differences in areas such as taxation and registration requirements. Nieuwland and van Melik [69] selected a group of cities where significant negative externalities of STRs had been reported: Amsterdam, Anaheim, Barcelona, Berlin, Denver, London, New Orleans, New York, Paris, San Francisco, and Santa Monica. These are not the cities with the greatest supply of STRs, but rather those where the mass media have reported the most negative externalities associated with Airbnb. This media attention has spurred the inclusion of STRs as a problem in the local political agenda. However, similar levels of tourism pressure can prompt different regulatory responses. Aguilera, Artioli and Colomb [70] found such differences in the types of regulation in force in Milan, Paris, and Barcelona, both in terms of the level of stringency (weak in Milan, intermediate in Paris, strong in Barcelona) and choice of policy sectors (sharing economy and tourism in Milan, housing and land use in Paris, urban planning and tourism in Barcelona). Lastly, Von Briel and Dolnicar [71] conducted a longitudinal study of regulations (2008-2020) and identified four types of city according to their regulatory response: "Liberal" cities (San Francisco, Hobart), "moderate" cities (Paris, Vienna), "moderate collaborative" cities (Amsterdam, Barcelona), and "protective" cities (Tokyo, London, Reykjavik, New York, Berlin).

Although few studies as yet have analysed local regulations on STRs from the perspective of urban planning, some notable examples include a series of contributions from the United States, where zoning forms a central component of urban planning [72]. Zoning has been used to achieve strict separation of uses in a quest to preserve the residential character of neighbourhoods. The advent of STRs has changed this residential character, and in response, zoning regulations have been modified to contain their expansion. Legal scholars such as Gottlieb [73] and more recently Scanlon [74] have examined the regulations adopted in different US cities and their judicial trajectory. Gurran [75], Gurran and Phibbs [76], and Gurran, Searle, and Phibbs [77] have also studied cities in the United States, although their most detailed analyses have focused on Sydney. In agreement with Palombo [65], they note that the voluntary market regulation advocated by the large platform companies "misses many of the traditional concerns that land use planners have about tourism accommodations, such as the opportunities to spatially cluster tourist facilities and services; the management of traffic, parking, and waste; building and urban design requirements to attenuate noise and privacy impacts; appropriate fire, safety, emergency, and disability access requirements; and likely levels of occupancy and potential overcrowding" [76] (p. 82). Consequently, there is a need to incorporate the debate on Airbnb into a new planning research agenda [75].

\section{Spanish Cities as a Subject of Study}

\subsection{Urban Planning and Tourism in Spanish Cities. General Framework}

This article focuses on policies to contain tourism activity in Spanish cities, and in particular local urban planning measures. These policies have been adopted in response to problems arising from the soaring number of visitors in the years prior to the COVID-19 pandemic. Aggravated by the proliferation of STRs advertised through platform companies such as Airbnb, the problems of overtourism have affected the historic centres of large cities, which have witnessed a new cycle of touristification [25,78]. The most negative effects of this new cycle have been condemned by a wide range of social movements and have prompted the strategies adopted by some local governments.

Urban planning is the central component of the urban policies applied in Spanish cities; however, urban planners have only just begun to include tourism as a regulated activity. Previously, in cities such as Granada, Seville, or Toledo, which have been major tourist destinations for over 100 years, explicit references to tourism in urban plans and programmes were negligible. Regulations pertaining to historic centres were aimed at achieving generic improvements in urban attractiveness by enhancing or creating cultural landmarks, adapting public space, and rehabilitating the historic fabric. The regulatory component of the plans established mechanisms for urban heritage protection and reg- 
ulated land uses. One of the goals was to safeguard the residential function of historic centres, which was threatened by processes as diverse as building deterioration and the shift towards the service economy. It is only in recent decades that urban planners have paid more attention to tourism, in the context of a neoliberal trend in urban policies that emphasises competitiveness and openness to the outside world. Since 2000, priority has been given to urban actions with greater external appeal and a more flexible approach has been adopted to activities directly or indirectly related to tourism, such as hospitality, commerce, and especially accommodation.

At the same time, a new area of research has emerged investigating the interrelationship between urban planning and tourism, based mainly on case studies. Nofre et al. [79] have shown that urban planning in La Barceloneta was geared towards transforming this part of Barcelona into a space for leisure and tourism consumption in the city centre. Marín et al. [80] have analysed an urban renewal project in the centre of Malaga, coordinated via a specific plan (PEPRI) and funded by the European Union's URBAN programme. Among its effects, this renovation has enhanced the area's tourism appeal and, more recently, has attracted mass tourism. However, the project did not achieve one of its other objectives, namely, to halt population decline in the city centre. Solís et al. [81] have studied processes affecting the historic centre of Toledo, where a series of urban policies have been instrumental in creating an unsustainable situation characterised by museumisation, touristification, and gentrification. From a perspective more focused on the practice of planning and taking as a reference the reflections in Ashworth and Tunbridge [82] on urban historic tourism, Brito [83] has raised the need for better coordination between urban, heritage and tourism management. More recently, Barrera and Escampa [84] have further developed this approach, noting that urban planning policies have a direct impact on several aspects that affect tourist use of historic cities: (1) Management of excessive visitor flows, whether spatial or temporal; (2) measures to avoid the creation of mono-functional tourist spaces; (3) demand for increasingly larger and more complex facilities; (4) access to and mobility within the historic city; and (5) over-exploitation of a small number of heritage sites while neglecting the rest.

In this context, Barcelona has received notable research attention, as the centre of political, media, and academic attention in Spain and abroad. Since 1992, when the city hosted the Olympic Games, Barcelona has been a successful tourism destination and its management approach has been emulated in numerous cities. However, critical voices have also emerged, condemning the negative effects associated with the transformation from a "city with tourism" to a "tourist city" [85]. In recent times, these effects have intensified, in parallel with the expansion of Airbnb accommodation [86]. Many residents have expressed their discontent with tourism activity and social movements have become "touristified". The term "tourism phobia" has even been coined. The arrival of the movement Barcelona en Común (BeC, Barcelona in Common) in local government (2015) ushered in a major revision of the city's tourism model that went beyond the measures to mitigate the negative effects of tourism proposed by previous governments [87]. Among other actions, the new government team has drafted a special urban plan for tourist accommodation (Spanish initials: PEUAT), an urban planning instrument for tourism activity that seeks to contain the proliferation of tourist accommodation. The impacts of tourism, Airbnb and STRs, social movements, "tourism phobia", the new tourism policy, and urban planning regulation through PEUAT and other instruments are all issues that have been explored in depth in a wide range of studies on Barcelona [61,86-89].

In Spain, the regulation of tourist accommodation depends on different tiers of government. Thus, regional governments are responsible for establishing the types of accommodation (e.g., hotels, hostels, apartments and campsites), the administrative registration system for companies, and inspection and sanction procedures. For each type of accommodation, conditions are established in terms of surface area, facilities, and services, generally grouped by quality levels. STRs have been the subject of specific regulation in recent years, since Spanish tenancy law explicitly excludes from its scope of application "the temporary 
transfer of the use of the entirety of a furnished and equipped home in conditions of immediate use, marketed or promoted via tourism supply channels and carried out for profit". Hence, regional governments have issued a series of regulations governing aspects such as the facilities required in the home, the procedure for starting the activity and administrative registration, obligations in relation to consumers (tourists), and sanctions. Although the regulations vary from region to region, in general they do not include references to the renting of independent rooms within a dwelling and aim to establish a regime comparable to other forms of accommodation.

Meanwhile, at the local level, tourist accommodation is mainly regulated through urban planning. The various types of accommodation are treated as a tertiary land use, with different levels of compatibility with residential use. Urban planning regulations, which form part of urban land use plans, regulate the procedure for implementing this land use, which entails obtaining a municipal licence and can even involve drawing up a specific plan. Usually, the regulation distinguishes between a change of use of an entire building (for example, to open a hotel) and a change of use that only affects a part of it (for example a hostel), and in this latter case, conditions are established in relation to the building's surface area and access. Furthermore, regulations must comply with the zoning system, which is particularly complex to manage in city centres. This approach was intended to regulate the use of hotels and other traditional establishments; however, the proliferation of STRs has posed a challenge in terms of planning, and one that has elicited very different responses.

\subsection{Research Method}

As indicated earlier, the present study focused on an analysis of local urban planning strategies that seek to contain tourism growth. Such actions generally take the form of regulations that render it difficult or even impossible to open new accommodation establishments, especially STRs. While recognising that Barcelona has led the way, here we broaden the scope to encompass a much wider range of Spanish urban destinations, adopting a comparative approach and taking as a reference other studies comparing the regulations enacted in various cities [67-71]. In comparing cities within the same country, this study follows in the footsteps of Gottlieb [73], Palombo [65], and Scanlon [74]. As Cassell and Deutsch indicated [66] (p. 2) in their study of German cities: "Comparing cities within a single country enables one to control for institutional variations in intergovernmental relations, cultural factors, national economy, and political institutions". In short, regulatory variations can be addressed within a common framework.

We employed a two-stage methodological approach. In the first stage, we reviewed the local governments' response to the effects of tourism growth and the possibilities of local control. The study period extended from 2015 until the emergence of the COVID-19 pandemic in early 2020. During this time, municipal elections were held (in 2015 and 2019), bringing significant changes in the governing parties. Our study encompassed 46 Spanish cities, including the largest urban agglomerations in Spain (e.g., Barcelona, Bilbao, Madrid, and Valencia), the historic cities traditionally associated with heritage and cultural tourism (e.g., Cordoba, Granada, Santiago de Compostela, and Toledo), and other medium-sized cities located on the coast, with different histories of tourism (e.g., A Coruña, Cadiz, and Donostia-San Sebastian). The main source of information for this study was news items in the mass media, which reports on local government positions concerning regulation and on regulatory variations over time. Relevant information was identified by means of key word searches. The use of news as a source is common in this field. In addition to reporting on institutional positions, the news also takes into account the political dynamics surrounding the inclusion of an issue on the urban agenda, the formulation of corresponding policies, and, where appropriate, the implementation of the measures adopted. Besides local government, such dynamics may include representatives of the conventional accommodation sector, platform companies such as Airbnb, owners of STRs, political parties, and social movements. Furthermore, we conducted an exploratory 
study of local government specialists' perceptions of the problems caused by tourism and the measures taken to mitigate them in the cities where they worked [90]. This study was based on a questionnaire completed by 113 local government specialists in 46 cities. Data were collected between May and September 2019, with the collaboration of the departments of tourism and urban planning of the Spanish Federation of Municipalities and Provinces.

The second stage focused on cities that had adopted urban planning regulations that imply stricter regulation of accommodation within a general framework of control of tourism growth. We analysed the following aspects in these cities: (1) Political composition of local government; (2) chronology of the regulation, with reference to prior studies, initial approval with suspension of licensing, definitive approval, and implementation; (3) regulatory instrument, considering aspects such as type of instrument, rationale, openness to contributions from stakeholders, scope of action (conventional accommodation and/or STRs, with the prescriptive regulatory definition of this), zoning strategy, and use of indicators; and (4) consistency with other measures adopted at local and regional level (e.g., taxation and marketing). In addition to the sources indicated for the first stage, we also analysed a comprehensive series of public policy documents related to the cities studied, consulted documents describing the positions of other stakeholders, and participated in events where the formulation and application of these policies in different cities were debated.

\section{Results. Urban Planning Regulations on Tourist Accommodation Uses in Spanish Cities}

\subsection{Local Government Positions on Regulation}

Before the outbreak of the COVID-19 epidemic, the debate on the regulation of tourist accommodation was in full swing. In general, the cities can be divided into three groups according to the local governments' position regarding regulation: (1) Cities where regulation had been rejected; (2) cities where the implementation of such regulations was being considered and the first official steps may even have been taken towards implementation; and (3) cities with fully operational regulations (Table 1).

Table 1. Cities according to the local governments' position regarding regulation.

\begin{tabular}{|c|c|}
\hline Group & $\begin{array}{l}\text { Cities (in Brackets, Declaration Date of the Historic Site and as World Heritage or } \\
\text { World Heritage Cities) }\end{array}$ \\
\hline Cities without Regulation & $\begin{array}{l}\text { Alcala de Henares (1968, WHC-1998), Almeria (1999), Avila (1982, WHC-1985), Caceres } \\
\text { (1949, WHC-1986), Cartagena (1980), Ceuta (1997), A Coruña (1944), Gijon (1975), Leon } \\
\text { (1962), Lugo (1973, WH-2000), Melilla (1953), Merida (1973, WHC-1993), Murcia (1976), } \\
\text { Ourense (1975), Pontevedra (1951), San Cristobal de La Laguna (1985, WHC-1999), } \\
\text { Santander (1986), Soria (1993), Teruel (1978, WH-1986), Valladolid (1978), Vigo (2006), } \\
\text { Zamora (1973), Zaragoza (2003, WH-2001) }\end{array}$ \\
\hline $\begin{array}{l}\text { Cities with Regulations under Study } \\
\text { or in Administrative Process (without } \\
\text { Final Approval) }\end{array}$ & $\begin{array}{l}\text { Burgos (1967, WH-1984), Cadiz (1972), Cordoba (1929, WHC-1984), Cuenca (1963, } \\
\text { WHC-1996), Eivissa (1969, WHC-1999), Girona (1967), Granada (1929, WH-1984), } \\
\text { Malaga (1967), Las Palmas de Gran Canaria (1973), Salamanca (1951, WHC-1988), } \\
\text { Sevilla (1990, WH-1987), Tarragona (1966, WHC-2000), Toledo (1940, WHC-1986), } \\
\text { Vitoria-Gasteiz (1988) }\end{array}$ \\
\hline Cities with Regulation & $\begin{array}{l}\text { Barcelona (varios años, WH-1984), Bilbao (1972, WC-2006), Donostia-San Sebastian } \\
\text { (1988), Madrid (1995), Palma de Mallorca (1964), Pamplona (1968), Santiago de } \\
\text { Compostela (1940, WHC-1985), Segovia (1941, WHC-1985), Valencia (1993, WH-1996) }\end{array}$ \\
\hline
\end{tabular}

Source: own elaboration.

However, almost all urban tourism destinations in Spain had been drawn into the debate on the need for much stricter regulation of accommodation, especially STRs. In many cities, the issue had entered the agenda, but local governments did not yet consider it a priority. In 23 of the 46 cities considered, news items on the subject in the local press were either non-existent or expressly referred to a lack of interest in regulation. In these cases, 
the general opinion was that the supply of STRs was limited and therefore did not cause any inconvenience to residents or distort the conventional tourist accommodation market. Instead, STRs were viewed as a new type of accommodation with the potential to boost tourism in the city. Consequently, regulation at regional level was considered sufficient and these local governments limited themselves to ensuring compliance by individuals with the licensing requirements established by the regional government for this type of accommodation (e.g., environmental impact report, certificate of habitability). This position was maintained in various types of destination, including incipient tourist destinations (A Coruña, Gijon, Teruel), historic cities with a long history of tourism (Avila, Caceres, Merida), and large urban agglomerations such as Zaragoza. Although not always the case, this position was more common among centre-right local governments.

The second group comprised 14 cities where the issue had been raised and regulatory measures were in the process of being adopted. In some cases, this process was in the very early stages and was mainly reflected in statements of intent by a member of the local government that been reported in the media. For example, in Gerona, the existence of STRs in the historic centre had been noted as problematic, spurring moves towards regulatory intervention. Similarly, there was awareness in Granada that neighbourhoods such as Albaicin and Realejo had reached saturation point in terms of STRs and that it would be necessary to establish limits by means of urban planning. This strategy was being employed in cities such as Cordoba and Malaga, which were studying planning modifications to achieve better regulation of STRs. In Salamanca, a draft ordinance had been presented and submitted for public inspection prior to subsequent inclusion into the city's urban planning strategy. In some destinations, regulation had already received initial approval, as in the case of Vitoria-Gasteiz and Toledo. In the latter city, one of Spain's main cultural tourism destinations, the provisionally approved ordinance limited STRs to homes that had been unoccupied for a year. However, the regulation would not come into full effect until obtaining final approval, and since March 2020, little progress has been made in this regard: With no tourists in the city, concerns have shifted elsewhere. Furthermore, many STRs are reverting to conventional rentals. All this has taken place in a context of changes in government in many cities, with greater control being wielded by liberal-conservative parties, which are generally more opposed to public intervention.

The process of formulating these policies is a long one, often taking several years. The first step is initial entry onto the agenda, when local governments become aware a problem that needs to be addressed. This may be as a result of new political parties entering local government, pressure from interest groups (e.g., residents or representatives of the conventional accommodation sector), or monitoring of approaches in other benchmark cities, in a process of public policy dissemination. The first official response to concern is often to commission a study aimed at quantifying the supply of STRs and assessing the measures adopted in other destinations. Such reports have been produced in cities such as Cordoba, Donostia-San Sebastian, Madrid, Palma de Mallorca, Santiago de Compostela, Tarragona, and Valencia. In the case of Malaga, the Urban Environment Observatory responsible for the study adopted a more complex approach based on global indicators of tourism pressure. In parallel, expert committees may be created within local governments, generally led by urban planning departments with participation from the tourism sector, with responsibility for preparing and submitting policy proposals for initial approval. In addition to the process of debate among local political parties, the legislation governing urban planning stipulates a process of public information and consultation to enable the participation of various social agents. Given that this is a standard bureaucratic procedure, cities such as Valencia and Vitoria-Gasteiz have taken measures to ensure that social participation is more open and transparent. At the end of the established period, the new regulation is definitively approved, although at some point prior to this approval, licensing of new accommodation is frequently suspended as a precautionary measure. Such suspension is not retroactive, even for licences that are still being processed. 
The third group comprised nine cities where regulation had been approved and was fully operational. Barcelona has led the way in this kind of intervention, and other Spanish cities have been adopting its management model since the 1990s. In 2014, Barcelona began to draw up its Special Plan for the Regulation of SRTs and the city council placed a moratorium on growth by suspending any award of new licences for this type of accommodation. In 2015, the new local government led by Barcelona en Común went a step further, launching the preparation and approval procedure of the PEUAT (Special Urban Plan for Tourist Accommodation) while simultaneously extending the moratorium on new licences to all types of tourist accommodation (e.g., hotels and hostels) until 2017, the year when the PEUAT was approved. Many cities followed Barcelona's example, adapting its model to local circumstances. In 2018, regulation was approved in Bilbao (February), Donostia-San Sebastian (March), Palma de Mallorca (July), and Santiago de Compostela (November). These were joined in 2019 by Madrid (March), Segovia (September), and Pamplona (December). In February 2020, just before the outbreak of the pandemic, regulation was definitively approved in Valencia. This group includes some of the largest cities in Spain, which are also the most popular urban destinations in Europe for international tourists. Ideological affinity has played a clear role in the spread of this policy, which has been adopted by predominantly left-wing and/or nationalist governments.

\subsection{Urban Planning Regulations on Accommodation: Instruments, Rationale, and Scope}

The legal instruments applied in the nine cities with regulations in force vary widely (Table 2). Donostia-San Sebastian has approved a simple ordinance regulating STRs and room rentals. Doubts about the legal validity of this instrument have led some cities to issue a similar ordinance and then incorporate its provisions into a modified general city plan. Such is the case of Palma de Mallorca. Other cities have modified the planning regulations on tourist accommodation within the general municipal plan and/or a special plan governing the historic centre (Bilbao, Pamplona and Santiago de Compostela). In the case of very recent urban plans (Segovia, Valencia), regulation of this land use is highly detailed. Meanwhile, Barcelona and Madrid have formulated special accommodation plans that specifically regulate licensing of this use in their municipal areas. Regardless of the nature of these plans and ordinances, legal appeals are frequently lodged against their provisions, which in some instances, causes an uncertain future for the instruments.

The rationale given for the adopted regulations is similar to that in other cities worldwide, although obviously adapted to the legal nature of urban planning instruments in Spain. The central argument is to contain tourism in urban centres because it puts pressure on the housing market by reducing the supply available for the resident population and also disrupts the everyday lives of said residents. Similarly, tourism tends to transform commercial activity in the neighbourhoods concerned, as businesses begin to cater to foreign demand. Furthermore, tourism accentuates processes of displacement, which particularly affect groups with less purchasing power. Although gentrification may sometimes be mentioned, the overriding concern is the risk of increasing depopulation, a concern that has been a constant refrain in urban plans for Spain's historic city centres since the 1970s. Safeguarding the heritage of historic centres-the central goal of special plans for protecting these urban areas-necessarily entails maintaining their resident populations in order to preserve the character of the areas in question and avoid their transformation into open-air museums or theme parks. Thus, containment of tourism activity, which is expressly associated with accommodation, implies preserving the urban model established in the plans regulating the city as a whole and/or its historic centre. For example, the provision of green spaces and facilities associated with residential use (e.g., schools, health centres, and sports facilities) is meaningless in neighbourhoods that are changing from being places of permanent residence to spaces for temporary tourist use. This explains the need to formulate a specific regulation for a phenomenon that did not even exist when many of the plans in force were approved. Such plans must be adapted to address this problem and to comply with recent regional legislation on tourism (and accommodation). 
Lastly, references to balancing the tourism offer (in the sense of advocating an equivalent framework for all forms of accommodation) also appear in the rationale given for new urban planning regulation instruments but are much less common.

The scope of the regulations is determined by the type of accommodation concerned and the regulatory content of the measures adopted. Regarding the first question, the regulation may govern room rentals, STRs, and conventional types of tourist accommodation. The regulatory content implies a modification of the measures that may go as far as total prohibition of the activity. In addition, the spatial distribution associated with zoning must be considered [91,92].

The regulation of room rentals for tourists is rare. In general, the instruments adopted refer to regional tourism regulations, which often prohibit this activity. In practice, this means it is included in residential use. However, some cities have regulated room rentals in more detail. For example, in Donostia-San Sebastian limits have been set on the surface area of a dwelling that can be used for this activity and minimum conditions of habitability have also been established. Meanwhile, in Pamplona, the regulation is similar for all types of accommodation.

The common basis of all regulation is the control of tourist use of an entire dwelling. A clear distinction is made between residential use of a dwelling and use as tourist accommodation, viewed as an economic activity equivalent to other types of accommodation that do not occupy the entire building (e.g., hostels and guest houses). This distinction may be absolute or dependent on considerations of time. For example, the regulations in Madrid and Valencia only affect dwellings used as tourist accommodation for more than 90 days a year and 60 days a year, respectively. If such use is considered equivalent to any another type of accommodation activity, it can be totally forbidden (Santiago de Compostela), or may be licensed in a building depending on a series of criteria:

- Type of building. Thus, within the urban area of Palma, STRs are only permitted in single-family dwellings (detached houses or villas).

- Access. The type of access may affect regulation, for example whether there is independent access from a public road or access involves using common spaces (e.g., the entrance hall, stairs or lift) in a building with other residential dwellings. Thus, in cities such as Madrid and Segovia, STRs are permitted where there is independent access.

- The position of the accommodation in the building. In general, tourist accommodation on the ground floor is permitted. Such spaces are usually old commercial establishments that have been converted into dwellings authorised for residential use (certificate of habitability). In some cases, restrictions may be placed on new tourist accommodation located on the first floor and/or floors immediately below those used for residential purposes. Measures of this type appear in the regulations in Bilbao and Donostia-San Sebastian.

- The number of STRs and the surface area they occupy within a building. The regulations in Donostia, Bilbao, and Pamplona apply these criteria. For example, in Pamplona, a single building may not contain more than one tourist accommodation establishment, including room rentals, and the total surface area dedicated to these uses may not exceed 200 square metres.

Although the drive for regulation emerged in response to a dramatic increase in STRs, some local governments have taken advantage of this to formulate much more detailed licensing regulations for conventional types of accommodation that occupy entire buildings, such as new hotels. This move has yielded urban planning instruments with much greater scope for intervention, such as the special accommodation plans in Barcelona and Madrid or special plans that specifically govern historic centres. In general, the regulations adopted prohibit licensing new hotel uses or limit this possibility to a much smaller number of buildings depending on their location, previous use, and/or heritage value. 
Table 2. Cities according to their regulation features.

\begin{tabular}{|c|c|c|c|c|c|c|}
\hline \multirow[b]{2}{*}{ City } & \multirow{2}{*}{$\begin{array}{c}\text { Regulation Instrument (and Date } \\
\text { of Approval) }\end{array}$} & \multirow[b]{2}{*}{ Government Party } & \multicolumn{2}{|c|}{ Type of Accommodation Concerned } & \multirow[b]{2}{*}{ Zoning } & \multirow{2}{*}{$\begin{array}{c}\text { Overnight Stays in Hotels Overnight } \\
\text { Stays/Inhabitants Airbnb Listings } \\
\text { (Whole Dwellings) }\end{array}$} \\
\hline & & & STRs & $\begin{array}{l}\text { Conventional } \\
\text { Accomodation }\end{array}$ & & \\
\hline Barcelona & $\begin{array}{l}\text { Special Urban Plan for Tourist } \\
\text { Accommodation (April 2016) }\end{array}$ & Barcelona en Comú & Yes & Yes & Explicit & $\begin{array}{c}21.361 .391 \\
13,05 \\
9.494(46,19 \%) \\
\end{array}$ \\
\hline Bilbao & $\begin{array}{l}\text { Detailed modification of the General Plan of } \\
\text { Urban Planning of Bilbao regarding the } \\
\text { regulation of the use of tourist } \\
\text { accommodation (February 2018) }\end{array}$ & PNV-PSOE & Yes & No & Implicit & $\begin{array}{c}1.888 .211 \\
5,44 \\
1.175(50,64 \%)\end{array}$ \\
\hline $\begin{array}{l}\text { Donostia-San } \\
\text { Sebastian }\end{array}$ & $\begin{array}{l}\text { Municipal ordinance regulating the use of } \\
\text { tourist accommodation and the rental of } \\
\text { rooms in the main residence for tourist use } \\
\text { (March 2018) }\end{array}$ & PNV-PSOE & Yes & No & Explicit & $\begin{array}{c}1.432 .822 \\
7,65 \\
1.682(71,28 \%)\end{array}$ \\
\hline Madrid & $\begin{array}{l}\text { Special Plan for Regulation of the Use of } \\
\text { Tertiary Services of Accomation (March 2019) }\end{array}$ & Ahora Madrid & Yes & Yes & Explicit & $\begin{array}{c}20.850 .285 \\
6,38 \\
13.100(60,09 \%) \\
\end{array}$ \\
\hline Pamplona & $\begin{array}{l}\text { Modification of article } 28 \text { of the Municipal } \\
\text { Plan, regarding the Regulation of } \\
\text { compatibility of uses (Temporary Residence). } \\
\text { Modification of Articles } 87 \text { and } 88 \text { of the } \\
\text { Special Plan for the Protection and Internal } \\
\text { Reform of the Old Town (December 2019) }\end{array}$ & $\begin{array}{l}\text { Euskal Herria Bildu, } \\
\text { en coalición con } \\
\text { Geroa Bai, Aranzadi } \\
\text { e Izquierda-Ezkerra }\end{array}$ & Yes & No & Implicit & $\begin{array}{c}691.228 \\
3,43 \\
\text { No data }\end{array}$ \\
\hline $\begin{array}{l}\text { Santiago de } \\
\text { Compostela }\end{array}$ & $\begin{array}{l}\text { Specific modification of the Special Plan for } \\
\text { the Protection and Restoration of the } \\
\text { Historical City (PE-1) to limit the temporary } \\
\text { accommodation in its residential building } \\
\text { (November 2018) }\end{array}$ & Compostela Aberta & Yes & No & Implicit & $\begin{array}{l}1.464 .632 \\
15,46 \\
\text { No data }\end{array}$ \\
\hline
\end{tabular}


Table 2. Cont

\begin{tabular}{|c|c|c|c|c|c|c|}
\hline \multirow[b]{2}{*}{ City } & \multirow{2}{*}{$\begin{array}{l}\text { Regulation Instrument (and Date } \\
\text { of Approval) }\end{array}$} & \multirow[b]{2}{*}{ Government Party } & \multicolumn{2}{|c|}{ Type of Accommodation Concerned } & \multirow[b]{2}{*}{ Zoning } & \multirow{2}{*}{$\begin{array}{c}\text { Overnight Stays in Hotels Overnight } \\
\text { Stays/Inhabitants Airbnb Listings } \\
\text { (Whole Dwellings) }\end{array}$} \\
\hline & & & STRs & $\begin{array}{l}\text { Conventional } \\
\text { Accomodation }\end{array}$ & & \\
\hline Segovia & $\begin{array}{l}\text { PEAHIS-Special Plan for Historic Areas } \\
\text { (September 2019) }\end{array}$ & PSOE & Yes & No & Implicit & $\begin{array}{l}534.057 \\
10,34 \\
\text { No data }\end{array}$ \\
\hline Valencia & $\begin{array}{l}\text { Special Protection Plan of Ciutat Vella } \\
\text { (February 2020) }\end{array}$ & Compromís & Yes & No & Implicit & $\begin{array}{c}4.352 .588 \\
5,48 \\
5.167(67,51 \%)\end{array}$ \\
\hline
\end{tabular}

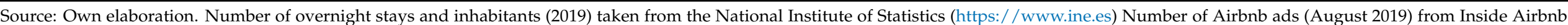
(http://insideairbnb.com). 
In general, such regulations apply the practice of zoning. All studies to date have found that tourism pressure is uneven, tending to be more intense in particular areas of urban centres of significant heritage value that have been affected by an earlier shift to the service economy that threatens their status as residential spaces and which therefore require preservation. Thus, the territorial strategy is to contain the growth of accommodation in central areas by implementing more restrictive measures. In contrast, measures in other parts of the city less affected by tourism are much more lenient. The idea behind this difference in regulation is to mitigate any risk to the tourism success of the destination as a whole by indirectly encouraging the expansion of tourism activities in peripheral areas.

In Barcelona, Madrid, and San Sebastian, an explicit zoning strategy has been established. As on other occasions, Barcelona led the way with its special plan that divides the city into four zones: Zone 1, aimed at reducing accommodation capacity (prohibition on opening new establishments, even if previous ones have shut down); Zone 2, aimed at maintaining the number of current establishments and beds (if an establishment closes, a new one with the same number of beds may be opened); Zone 3, aimed at contained growth, where new establishments may be opened or existing ones extended; and Zone 4 , corresponding to particular neighbourhoods with specific regulations. This zoning affects all types of accommodation. In addition, the plan establishes zero growth for STRs throughout the city, restricting new licences in saturated areas to cases where a previous establishment of identical characteristics has closed. The zoning in Madrid is similar. Again, the city has been divided into four areas, in the form of concentric rings, and restrictions on transforming an entire building for use as tourist accommodation become more stringent towards the centre. In fact, the regulations require separate access for tourist accommodation in the two central rings, which in practice means that it is prohibited. In Donostia-San Sebastian, three zones have been established: Zone A, which has reached saturation point, where STRs and room rentals are totally prohibited; Zone B, of high demand; and Zone C, where licences for new accommodation are possible. This regulation does not affect conventional types of tourist accommodation, which continue to be governed by the provisions of the city's general plan.

As noted, the most restrictive regulation corresponds to the historic centre of each city, the neighbourhoods that comprise the pre-industrial city. In Barcelona, Zone 1 includes Ciutat Vella but also extends to other highly popular tourist areas such as l'Antiga Esquerra de l'Eixample, Dreta de l'Eixample, part of the Sant Antoni district, Poble-sec, Hostafrancs, Vila de Gràcia, Vila Olimpica, and Poblenou. In Madrid, Ring 1 comprises the central district while Ring 2 includes the rest of the zone declared a historic site, primarily the area corresponding to nineteenth-century expansion. In Donostia-San Sebastian, Zone A corresponds to the old part located within the old city wall.

In the rest of the cities that have adopted regulations, however, zoning is merely implicit. In other words, the new regulations are established as special plans that only govern the historic centres, which implies a differentiated, more restrictive approach with respect to the rest of the urban agglomeration. Such is the case in Segovia and Santiago de Compostela, although in this latter the prohibition on licensing new accommodation establishments has been extended to the rest of the city as a precautionary measure. In Bilbao and Pamplona, planning modifications have affected the cities' general plans and imposed stricter regulations in the plans governing their historic centres. Even the Special Protection Plan of Ciutat Vella in Valencia distinguishes between two areas: The area classified as being for residential use, where new STRs available for more than 60 days a year and new hotels are prohibited; and the area classified as being exclusively for tertiary use, where entire buildings may be used for different tertiary purposes.

In general terms, this group of cities has moved towards a global policy of containing tourism activity, within which urban planning regulations are only one of the instruments employed, although perhaps the most powerful and effective. In Barcelona, the first measures adopted were aligned with the 2010-2015 Strategic Tourism Plan, and this approach became more clearly defined in the 2015-2019 term of office, when the Special Plan for 
Tourist Accommodation and the Strategic Tourism Plan 2020 were approved. In addition, efforts have been made to limit the movement of cruise ships and a local surcharge on the regional tourism tax is envisaged. In Donostia-San Sebastian, the municipal ordinance on STRs is generally consonant with the 2017-2021 Tourism Master Plan. Here too, the local government has envisaged the introduction of a tourism tax. In Madrid, efforts have been made to extend the tourist area to outlying districts by means of specific marketing campaigns ("Madrid, 21 Districts") and a more even distribution of major events throughout the city. In Santiago de Compostela, urban and tourism planning instruments have for many years reflected concern about excessive tourism pressure. In fact, in September 2020, a tourism sustainability plan was approved that aims to manage the city's tourist flows, encouraging decongestion of the most saturated areas by promoting less well-known heritage sites and varied, decentralised cultural activities.

Consistency with regional government policies is much more variable. The scope for action of regional governments comprises wider territories that include destinations with overtourism and others that need greater tourism growth as a development mechanism. This tension is reflected in the imposition of taxes on tourist overnight stays. Since taxation is a regional power, its use by local authorities is very limited, despite the fact that many have repeatedly requested it as a revenue-generating mechanism and a measure to control the flow of tourists. When the problem identified and the political parties in power are the same at regional and local level, the regulations are much more aligned. For example, the ordinance on STRs in Palma is consistent with the general thrust of the Island Plan for Tourist Accommodation in Mallorca, whereas the regulation of STRs applied in the city of Madrid has been continuously called into question by the regional government, led by an opposing political party.

\section{Discussion}

The effects of overtourism in urban tourism destinations are particularly evident in the historic centres of Spanish cities, which host the majority of tourism attractions and therefore receive most visitors. In recent years, the supply of tourist accommodation, in particular STRs, has witnessed dramatic, unbridled growth, shattering the functional balance of central urban spaces and triggering residential displacement, tourism gentrification, and/or touristification. As in other cities around the world, the proliferation of STRs in Spanish cities is a disruptive phenomenon. Given the many negative externalities of STRs, some cities have consequently adopted regulations of varying types and stringency.

The literature on the subject identifies a broad set of regulatory measures that include zoning conditions, taxation, insurance and civil liability, licensing and administrative registration for new accommodation, habitability, public safety, and length of tourist occupation. Given the framework of powers applicable to Spanish cities, some of these measures correspond to regional governments and others to local governments. In general, the regional government establishes the operational rules for the various types of accommodation through sectoral legislation regulating an economic activity. In contrast, local governments approach accommodation as a land use, which must be compatible with the other characteristic uses of each part of the urban space. Given these objectives, urban planning represents a very interventionist type of public policy and local governments have begun to make heavy use of it to contain the situations and processes encapsulated in the term overtourism. As has been reported in other countries, there is considerable strain between economic and urban planning visions in Spain.

Cities can be classified according to their different regulatory positions depending on the scope and stringency of their regulations $[65,66,69,71]$. Although these positions may be given different names, there are three main levels: (1) Laissez-faire, allowing STRs and room rentals without any local restrictions; (2) partially limited, permitting these activities but subject to a series of specific local conditions in each city; and (3) total prohibition, rendering this activity illegal. In Spain, the first level of laissez-faire encompasses a large number of urban destinations that have rejected local regulation. These are places where 
the apparent presence of STRs is limited and no urban problems associated with this type of accommodation have been identified. The local governments apply regional tourism regulations, and where required, facilitate the administrative procedures that these regulations establish at municipal level.

The next two levels comprise cities with regulations in place, but also those that were developing and processing instruments of this type prior to the emergence of the COVID19 pandemic. These include Spain's main cities (e.g., Barcelona, Bilbao, Madrid, Malaga, Seville, and Valencia) with major international connections, as well as smaller historic cities with a long history of tourism, such as Cordoba and Santiago de Compostela, and less popular destinations that have adopted these regulations in imitation of other cities experiencing greater tourism pressure. Since tourism pressure is uneven within each city, such regulations have been tailored to explicit and implicit zoning schemes. The greatest problems associated with overtourism occur in urban centres, which is why it is useful to identify the levels of regulatory stringency specifically in these areas. It is also helpful to focus on the real possibilities of opening new tourist accommodation, as sometimes the regulations do not legally prevent this activity but do establish conditions that are practically impossible to meet in Spanish historic centres (e.g., single-family residential dwellings or dwellings in multi-family buildings with independent access).

Of the cities analysed, Barcelona has the most restrictive regulation. In Zone 1, which includes the city's historic centre, the regulation seeks to reduce accommodation stock by prohibiting the establishment of any new accommodation facilities. This regulation is closest to the degrowth approach applied in the tourism sector [93-95]. In all the other cities, regulation is less restrictive and depends on the type of accommodation in question and/or the conditions imposed on issuing new licences. Madrid's special plan also greatly limits the transformation of entire buildings into hotels within the central district and in practice renders it impossible to open STRs, although this only applies to dwellings available for more than 90 days a year. A time restriction is also applied in the historic centre of Valencia, with a limit of 60 days placed on STRs in buildings of a predominantly residential nature. In the historic centre of Donostia-San Sebastian, STRs and room rentals are prohibited, as they are in the entire urban area of Palma de Mallorca. In Bilbao and Pamplona, the award of new licences is limited by regulating access conditions and the location and density of accommodation within a building.

As mentioned above, Barcelona has set the standard for regulation, as its local government was the first to use urban planning instruments to contain tourism activity. Although this type of instrument had already been used in sun and beach destinations to impose a moratorium on tourism growth [96-98], and in many cities to avoid the proliferation of hotel and catering establishments, a source of conflict with residents, it had never been used before to contain the growth of tourism activity in urban centres by setting limits inherent to the concept of sustainability [99-102]. Barcelona's experience has also provided a rationale for the regulations adopted as an attempt to contain tourism, defend residents' right to the city, and contain processes of residential displacement and tourist gentrification [103]. Thus, Barcelona was the first city to implement a series of urban planning measures aimed at regulating new STRs by introducing quantitative, qualitative, and location-related restrictions [69]. Transfer of this model has been easy because local government and urban planning frameworks are the same throughout Spain, although each city has adapted the model to local circumstances. The transfer is evident not only in cities with regulations in force, but also in those where regulation has not yet received final approval (e.g., Cordoba, Malaga, Seville, Toledo, and Vitoria-Gasteiz). The experience garnered has helped to generate increasingly sophisticated regulations and has highlighted the need to link these to other urban management measures that are not limited to the tourism sector. In addition to regulating permission for new hotel and catering establishments, key measures have been adopted regulating outdoor bar or restaurant seating on public thoroughfares and noise pollution control, especially at night. 
However, urban planning regulations are not without their problems. While their overall rationale is consistent, identifying when and where overtourism occurs is extremely difficult $[104,105]$. Setting thresholds is essential to establish limits, a task inherent in adopting restrictions that will affect all or part of a destination according to the zoning applied. At the same time, legal appeals are frequently lodged against this type of regulation on procedural and/or substantive grounds, funded by owners' associations, tourist accommodation developers, and public entities responsible for ensuring fair competition. According to th latter, this type of regulation prevents the proper functioning of the free market as it introduces obstacles to the incorporation of new actors in the accommodation sector. It also impedes the development of the digital economy. Once legal proceedings have been initiated, the results are unpredictable and legal uncertainty is high. Another issue is change in the parties and coalitions governing the cities, which may usher in significant modifications to the overall thrust of the regulations or to the effective application of those already in force, especially as regards inspections and sanctions.

Beyond these specific questions, the greatest limitations stem from the actual capacity of urban planning regulations to deal with overtourism. These regulations have proven effective as regards permission for new land uses in the case of transforming residential buildings into hotels or other conventional accommodation establishments. However, their use as regards STRs is much more problematic. In these cases, the goal is to determine whether a dwelling is for residential or tourist use, and to apply the established time restrictions. Irrespective of the provisions of the regulations, proving situations of illegality that attract sanctions is a very complex task, so much so that the bureaucracy involved may discourage local administrations from taking this route of intervention. Although these are large cities, their local governments have a very limited capacity to impose conditions on companies such as Airbnb, which is why this and other companies only collaborate in the implementation of regulations if they obtain favourable frameworks for action. This may be the underlying cause of the "liberal" positions of some destinations. The tensions involved in regulation reflect the asymmetry between global companies and local governments. At a global level, analyses performed to date do not indicate a significant reduction in the supply of STRs in cities where limitations have been applied [71]. However, in some cases, there has been a reduction in supply in central areas paralleled by growth in peripheral areas, in accordance with the established zoning schemes [64]. As with other activities, the adoption of urban planning regulations does not completely prevent the creation of new establishments but does imply a "cooling off" of the market, as it reduces expectations of quick and easy profits. However, since the regulations are not retroactive, transitional periods have meant that much of the supply that would have been unable to operate under the new conditions has been legalised.

\section{Conclusions}

Here, we have reviewed the main urban planning regulations on tourism in Spanish cities. To date, this is the first overview to conduct an in-depth analysis of the details and scope of urban planning regulations (the heart of intervention in Spanish cities). We have adopted a comparative approach to move beyond the exceptionality of case studies. The study, carried out on a sample of 46 Spanish cities, has allowed the identification of a wide group of cities ( $50 \%$ of the sample) that have begun to regulate tourism via urban planning, although only in 9 of them are the measures in force (regulations definitively approved). The regulation is focused on the accommodation sector and affects mainly dwellings for tourist use. It is justified in terms of protecting residential activity and stopping the processes of touristification and residential displacement, in line with the approaches of other cities in the world. However, the perception of the scope of these phenomena and their interpretation in terms of the problem/challenge varies from one city to another depending on the political orientation of the local government. In this sense, we can even observe processes of mimicry that transfer the interpretation of the problems of overtourism/touristification and the type of measures adopted from the largest and 
most important tourist cities (Madrid, Palma de Mallorca, but above all Barcelona) to other smaller historical cities.

Generally speaking, our results demonstrate the difficulties entailed in the process of formulating and applying regulations and reveal imbalances at two levels: (1) Between economic and urban planning visions; and (2) between the dizzying and disruptive speed of change in tourism and the much slower response capacity of governments. We are facing administrative processes of slow processing that show an inadequate response capacity to the speed of change of the tourist activity in the city.

Besides, the research has focused on the identification and analysis of the instruments and measures of regulation adopted. However, given the scarce time span of their application, it remains pending for future research to study the impact that these measures have on the evolution of tourist activity in the urban space in order to evaluate their effectiveness. In this sense, our study also opens up new fields of research in an agenda marked by the uncertainty of an anxiously awaited post-pandemic recovery. In fact, one should bear in mind that the regulations analysed were drawn up in a context of overtourism, where the rapid proliferation of tourism activity had disrupted urban centres. The outbreak of the COVID-19 pandemic in the spring of 2020 has halted the flow of tourism and suspended previous tourism processes. Many hotel projects have come to a standstill and property owners are once again offering their dwellings for long-term residential rental. Nonetheless, the regulations remain. Again, strain has emerged between the speed of change affecting many economic and social processes and the slow responses of governments at different levels.

In the future, once the pandemic has been controlled, situations and processes of overtourism are likely to resurface with renewed intensity, and when they do, urban regulation measures will constitute the basic instrument available to local governments. However, control measures must be accompanied by actions aimed at activating peripheral nodes to disperse the flow of tourism throughout the city. Furthermore, urban planning measures must form part of a more global policy of containment and redistribution that includes marketing measures, accessibility and mobility control, and intelligent solutions. This would contribute to achieving more sustainable tourism in more sustainable cities.

Author Contributions: Conceptualization and design, M.d.l.C.-V.; methodology, M.d.l.C.-V. and M.G.-H.; literature review and data collection, S.M.d.M.; data analysis, M.d.l.C.-V. and M.G.-H.; conclusions, M.G.-H.; writing, M.d.l.C.-V., M.G.-H., and S.M.d.M. All authors have read and agreed to the published version of the manuscript.

Funding: This research was funded by the Ministry of Economy and Competitiveness. Research project: Transformations of the historical urban landscape caused by tourism: contradictions and controversies, government and governance (CSO2016-75470-R). It has also been possible with the support of the Ministerio de Ciencia, Innovación y Universidades: Doctoral Research Grant FPU17/02402.

Data Availability Statement: All the data are public and accessible on the local governments' official websites of the consulted cities and in the local press.

Conflicts of Interest: The authors declare no conflict of interest.

\section{References}

1. Agyeiwaah, E. Over-tourism and sustainable consumption of resources through sharing: The role of government. Int. J. Tour. Cities 2019, 6, 99-116. [CrossRef]

2. Bouchon, F.; Rauscher, M. Cities and tourism, a love and hate story; towards a conceptual framework for urban overtourism management. Int. J. Tour. Cities 2019, 5, 598-619. [CrossRef]

3. Durieux Zucco, F.; Flores Limberger, P.; de Souza Farias, F.; Foletto Fiuza, T.F.; Boos de Quadros, C.M. The relationship of subjective well-being in residents' perceptions of the impacts of overtourism in the city of Blumenau, Santa Catarina, Brazil. Sustainability 2020, 12, 1957. [CrossRef]

4. WTTC \& McKinsey \& Company. Coping with Success Managing Overcrowding in Tourism Destinations; McKinsey \& Company and World Travel \& Tourism Council: London, UK, 2017. 
5. $\quad$ Peeters, P.; Gössling, S.; Klijs, J.; Milano, C.; Novelli, M.; Dijkmans, C.; Eijgelaar, E.; Hartman, S.; Heslinga, J.; Isaac, R.; et al. Research for TRAN Committee-Overtourism: Impact and Possible Policy Responses; European Parliament, Policy Department for Structural and Cohesion Policies: Brussels, Belgium, 2018.

6. Martín Martín, J.M.; Guaita Martínez, J.M.; Salinas Fernández, J.A. An analysis of the factors behind the citizen's attitude of rejection towards tourism in a context of overtourism and economic dependence on this activity. Sustainability 2018, $10,2851$. [CrossRef]

7. Cardoso, C.; Silva, M. Residents' perceptions and attitudes towards future tourism development: A challenge for tourism planners. Worldw Hosp. Tour. Themes 2018, 10, 688-697. [CrossRef]

8. Smith, M.K.; Pinke Sziva, I.; Olt, G. Overtourism and Resident Resistance in Budapest. Tour. Plan. Dev. 2019, 16, 376-392. [CrossRef]

9. Alonso-Almeida, M.M.; Borrajo-Millán, F.; Yi, L. Are Social Media Data Pushing Overtourism? The Case of Barcelona and Chinese Tourists. Sustainability 2019, 11, 3356. [CrossRef]

10. Kruczek, Z. Ways to Counteract the Negative Effects of Overtourism at Tourist Attractions and Destinations. Ann. Univ. Mariae Curie-Skłodowska Sect. B 2019, 74, 45-57. [CrossRef]

11. Benner, M. Overcoming overtourism in Europe: Towards an institutional-behavioral research agenda. Z. Wirtsch. 2019, 64, 74-87. [CrossRef]

12. Pechlaner, H.; Innerhofer, E.; Erschbamer, G. Overtourism: Tourism Management and Solutions; Routledge: Abingdon, UK, 2019.

13. Atzori, R. Destination stakeholders' perceptions of overtourism impacts, causes, and responses: The case of Big Sur, California. J. Destin. Mark. Manag. 2020, 17, 100440. [CrossRef]

14. Benner, M. The Decline of Tourist Destinations: An Evolutionary Perspective on Overtourism. Sustainability 2020, $12,3653$. [CrossRef]

15. Pasquinelli, C.; Trunfio, M. Reframing urban overtourism through the Smart-City Lens. Cities 2020, 102, 102729. [CrossRef]

16. Koens, K.; Postma, A.; Papp, B. Is Overtourism Overused? Understanding the Impact of Tourism in a City Context. Sustainability 2018, 10, 4384. [CrossRef]

17. Perles-Ribes, J.F.; Ramón-Rodríguez, A.B.; Moreno-Izquierdo, L.; Such-Devesa, M.J. Machine learning techniques as a tool for predicting overtourism: The case of Spain. Int. J. Tour. Res. 2020, 22, 825-838. [CrossRef]

18. Ebejer, J. Case Study 1: Overtourism in Valletta-Reality or Myth? In Overtourism: Causes, Implications and Solutions; Séraphin, H., Gladkikh, T., Thanh, T.V., Eds.; Palgrave Macmillan: London, UK, 2020; pp. 107-128.

19. Kušcer, K.; Mihalic, T. Residents ' Attitudes towards Overtourism from the Perspective of Tourism Impacts and Cooperation-The Case of Ljubljana. Sustainability 2019, 11, 1823. [CrossRef]

20. Nilsson, J.H. Conceptualizing and contextualizing overtourism: The dynamics of accelerating urban tourism. Int. J. Tour. Cities 2020, 6. [CrossRef]

21. De Luca, G.; Shirvani Dastgerdi, A.; Francini, C.; Liberatore, G. Sustainable Cultural Heritage Planning and Management of Overtourism in Art Cities: Lessons from Atlas World Heritage. Sustainability 2020, 12, 3929. [CrossRef]

22. Liberatore, G.; Biagioni, P.; Talia, V.; Francini, C. Overtourism in Cities of Art: A Framework for Measuring Tourism Carrying Capacity. SSRN Electron. J. 2019, September 2, 1-28. [CrossRef]

23. Briguglio, L.; Avellino, M. Has overtourism reached the Maltese Islands? Occas. Pap. Isl. Small States 2019, 1, 1-27.

24. Jordan, P.; Pastras, P.; Psarros, M. Managing Tourism Growth in Europe; The ECM ToolBox: Dijon, France, 2018.

25. De la Calle Vaquero, M. Turistificación de centros urbanos: Clarificando el debate. Bol. Asoc. Geógr. Esp. 2019, 83, 1-40. [CrossRef]

26. Del Romero Renau, L. Touristification, Sharing Economies and the New Geography of Urban Conflicts. Urban Sci. 2018, 2, 104. [CrossRef]

27. Freytag, T.; Bauder, M. Bottom-up touristification and urban transformations in Paris. Tour Geogr. 2018, 20, 443-460. [CrossRef]

28. Mínguez, C.; Piñeira, M.J.; Fernández-Tabales, A. Social vulnerability and touristification of historic centers. Sustainability 2019, 11, 4478. [CrossRef]

29. Ojeda, A.B.; Kieffer, M. Touristification. Empty concept or element of analysis in tourism geography? Geoforum 2020, 115, 143-145. [CrossRef] [PubMed]

30. Sequera, J.; Nofre, J. Shaken, not stirred: New debates on touristification and the limits of gentrification. City 2018, 22, 843-855. [CrossRef]

31. Cócola Gant, A. Holiday rentals: The new gentrification battlefront. Sociol. Res. Online 2016, 21, 112-120. [CrossRef]

32. González-Pérez, J.M. The dispute over tourist cities. Tourism gentrification in the historic Centre of Palma (Majorca, Spain). Tour. Geogr. 2019, 22, 171-191.

33. Pinkster, F.M.; Boterman, W.R. When the spell is broken: Gentrification, urban tourism and privileged discontent in the Amsterdam canal district. Cult. Geogr. 2017, 24, 457-472. [CrossRef]

34. Wachsmuth, D.; Weisler, A. Airbnb and the rent gap: Gentrification through the sharing economy. EPA Econ. Space 2018, 50, 1147-1170. [CrossRef]

35. Gravari-Barbas, M.; Guinand, S. Tourism and Gentrification in Contemporary Metropolises; International Perspectives, Routledge: London, UK, 2017.

36. Zmyślony, P.; Leszczyński, G.; Waligóra, A.; Alejziak, W. The Sharing Economy and Sustainability of Urban Destinations in the (Over)tourism Context: The Social Capital Theory Perspective. Sustainability 2020, 12, 2310. [CrossRef] 
37. Żemła, M. Reasons and Consequences of Overtourism in Contemporary Cities-Knowledge Gaps and Future Research. Sustainability 2020, 12, 1729. [CrossRef]

38. Fedyk, W.; Sołtysik, M.; Olearnik, J.; Barwicka, K.; Mucha, A. How Overtourism Threatens Large Urban Areas: A Case Study of the City of Wrocław, Poland. Sustainability 2020, 12, 1783. [CrossRef]

39. Mihalic, T. Concpetualising overtourism: A sustainability approach. Ann. Tour. Res. 2020, 84, 103025. [CrossRef]

40. Capocchi, A.; Vallone, C.; Amaduzzi, A.; Pierotti, M. Is 'overtourism' a new issue in tourism development or just a new term for an already known phenomenon? Curr. Issues Tour. 2019, 23, 2235-2239. [CrossRef]

41. Milano, C. Overtourism, malestar social y turismofobia. Un debate ontrovertido. Pasos 2018, 16, 551-564. [CrossRef]

42. Abbasian, S.; Onn, G.; Arnautovic, D. Overtourism in Dubrovnik in the eyes of local tourism employees: A qualitative study. Cogent Soc. Sci. 2020, 6, 1775944. [CrossRef]

43. Eckert, C.; Zacher, D.; Pechlaner, H.; Namberger, P.; Schmude, J. Strategies and measures directed towards overtourism: A perspective of European DMOs. Int. J. Tour. Cities 2019, 5, 639-655. [CrossRef]

44. Veríssimo, M.; Moraes, M.; Breda, Z.; Guizi, A.; Costa, C. Overtourism and tourismphobia: A systematic literature review. Tourism 2020, 68, 156-169. [CrossRef]

45. Mendoza de Miguel, S.; Calle Vaquero, M.; de la y García Hernández, M. Gestión de la saturación turística en destinos urbanos. In De Lugar Geográfico a Destino Turístico. Análisis, Planificación y Gestión de los Procesos de Cambio Generados por el Turismo; Somoza Medina, X., Ed.; Universidad de León y Asociación de Geógrafos Españoles: León, Spain, 2018; pp. $275-286$.

46. Blanco, I.; Subirats, J. Políticas urbanas en España. Dinámicas de transformación y retos ante la crisis. Geopolit. Rev. Estud. Sobre Espac. Pod. 2012, 3, 15-33.

47. Dredge, D.; Moore, S. A methodology for the integration of tourism in town planning. J. Tour. Stud. 1992, 3, 8-21.

48. Costa, C. An emerging tourism planning paradigm? A comparative analysis between town and tourism planning. Int. J. Tour. Res. 2001, 3, 425-441. [CrossRef]

49. Dredge, D. Destination place planning and design. Ann. Tour. Res. 1999, 26, 772-791. [CrossRef]

50. Inskeep, E. An Emerging Specialization. J. Am. Plan. Assoc. 1988, 54, 360-372. [CrossRef]

51. Larsen, J. Ordinary Tourism and Extraordinary Everyday Life: Re-thinking Tourism and Cities. In Tourism and Everyday Life in the Contemporary City; Frisch, T., Sommer, C., Stoltenberg, L., Stors, N., Eds.; Routledge: London, UK, 2019; p. 272.

52. Shoval, N. Urban planning and tourism in European cities. Tour. Geogr. 2018, 20, 371-376. [CrossRef]

53. Panayiotopoulos, A.; Pisano, C. Overtourism Dystopias and Socialist Utopias: Towards an Urban Armature for Dubrovnik. Tour. Plan. Dev. 2019, 16, 393-410. [CrossRef]

54. Smith, M.K.; Egedy, T.; Csizmady, A.; Jancsik, A.; Olt, G.; Michalkó, G. Non-planning and tourism consumption in Budapest inner city. Tour. Geogr. 2017, 20, 524-548. [CrossRef]

55. Nilsson, J.H. Urban bicycle tourism: Path dependencies and innovation in Greater Copenhagen. J. Sustain. Tour. 2019, 27, 1648-1662. [CrossRef]

56. Cró, S.; Martins, A.M. Hotel and hostel location in Lisbon: Looking for their determinants. Tour. Geogr. 2018, 20, 504-523. [CrossRef]

57. Kádár, B. Hotel development through centralized to liberalized planning procedures: Prague lost in transition. Tour Geogr. 2018, 20, 461-480. [CrossRef]

58. Guttentag, D. Airbnb: Disruptive innovation and the rise of an informal tourism accommodation sector. Curr. Issues Tour. 2015, 18, 1192-1217. [CrossRef]

59. Guttentag, D. Regulating Innovation in the Collaborative Economy: An Examination of Airbnb's Early Legal Issues. In Collaborative Economy and Tourism. Tourism on the Verge; Dredge, D., Gyimóthy, S., Eds.; Springer: Cham, Switzerland, 2017.

60. Artioli, F. Digital platforms and cities: A literature review for urban research. In Cities Are back in Town Working Papers; Sciences-Po Urban School: Paris, France, 2018; Volume 1, pp. 1-34.

61. Lambea Llop, N. A policy approach to the impact of tourist dwellings in condominiums and neighbourhoods in Barcelona. Urban Res. Pract. 2016, 10, 120-129. [CrossRef]

62. Schäfer, P.; Braun, N. Misuse through short-term rentals on the Berlin housing market. Int. J. Hous. Mark. Anal. 2016, 9, $287-311$. [CrossRef]

63. Ferreri, M.; Sanyal, R. Platform economies and urban planning: Airbnb and regulated deregulation in London. Urban Stud. 2018, 55, 3353-3368. [CrossRef]

64. Van Holm, E.J. Evaluating the impact of short-term rental regulations on Airbnb in New Orleans. Cities 2020, $104,102803$. [CrossRef]

65. Palombo, D. A Tale of Two Cities: The Regulatory Battle to Incorporate Short-Term Residential Rentals into Modern Law. Am. Univ. Bus. Law Rev. 2015, 4, 287.

66. Cassell, M.K.; Deutsch, A.M. Urban Challenges and the Gig Economy: How German Cities Cope with the Rise of Airbnb. Ger. Politics 2020, 1-22. [CrossRef]

67. Dredge, D.; Gyimóthy, S.; Birkbak, A.; Jensen, T.E.; Madsen, A.K. The Impact of Regulatory Approaches Targeting Collaborative Economy in the Tourism Accommodation Sector: Barcelona, Berlin, Amsterdam and Paris; Impulse Paper No. 9 Prepared for the European Commission DG GROWTH; Aalborg University: Copenhagen, Denmark, 2016. 
68. Hajibaba, H.; Dolnicar, S. Regulatory Reactions Around the World. In Peer-To-Peer Accommodation Networks: Pushing the Boundaries; Dolnicar, S., Ed.; Goodfellow Publishers: Oxford, UK, 2017; pp. 120-136.

69. Nieuwland, S.; van Melik, R. Regulating Airbnb: How cities deal with perceived negative externalities of short-term rentals. Curr. Issues Tour. 2018, 1-15. [CrossRef]

70. Aguilera, T.; Artioli, F.; Colomb, C. Explaining the diversity of policy responses to platform-mediated short-term rentals in European cities: A comparison of Barcelona, Paris and Milan. EPA Econ. Space 2019, 1-24. [CrossRef]

71. Von Briel, D.; Dolnicar, S. The evolution of Airbnb regulation-An international longitudinal investigation 2008-2020. Ann. Tour. Res. 2020, 1-5. [CrossRef]

72. Hirt, S. Form Follows Function? How America Zones. Plan. Pract. Res. 2013, 28, 204-230. [CrossRef]

73. Gottlieb, C. Residential Short-Term Rentals: Should Local Governments Regulate the 'Industry'? Plan. Environ. Law Issues Decis. Impact Built Nat. Environ. 2013, 65, 4-9. [CrossRef]

74. Scanlon, C. Re-zoning the Sharing Economy: Municipal Authority to Regulate Short-Term Rentals of Real Property. SMUL Rev. 2017, 70, 563.

75. Gurran, N. Global Home-Sharing, Local Communities and the Airbnb Debate: A Planning Research Agenda. Plan. Theory Pract. 2018, 19, 298-304. [CrossRef]

76. Gurran, N.; Phibbs, P. When Tourists Move In: How Should Urban Planners Respond to Airbnb? J. Am. Plan. Assoc. 2017, 83, 80-92. [CrossRef]

77. Gurran, N.; Searle, G.; Phibbs, P. Urban Planning in the Age of Airbnb: Coase, Property Rights, and Spatial Regulation. Urban Policy Res. 2018, 36, 99-416. [CrossRef]

78. De la Calle Vaquero, M.; García Hernández, M. Turismo, patrimonio y centros urbanos: ¿hacia un nuevo ciclo de turistificación? In Sostenibilidad Turística: Overtourism vs Undertourism; Pons, G.X., Blanco-Romero, A., Navalón-García, R., Troitiño-Torralba, L., Blázquez-Salom, M., Eds.; Monogr. la Soc. d'Història Nat. de les Balear.: Palma, Spain, 2020; Volume 31, pp. 135-146.

79. Nofre, J.; Giordano, E.; Eldridge, A.; Martins, J.C.; Sequera, J. Tourism, nightlife and planning: Challenges and opportunities for community liveability in La Barceloneta. Tour. Geogr. 2018, 20, 377-396. [CrossRef]

80. Marín, P.; Guevara, A.; Navarro-Jurado, E. Renovación urbana y masificación turística en la ciudad antigua. Ciudad Territ. Estud. Territ. CyTET XLIX 2017, 193, 454-468.

81. Solís, E.; Escudero, L.A.; Ruiz Apilánez, B. Los retos de la ciudad compacta desde la perspectiva de los cascos históricos con fuerte actividad turística. El caso de Toledo. Estud. Geogr. 2020, 81, 1-23. [CrossRef]

82. Ashworth, G.J.; Tunbridge, J.E. The Tourist-Historic City; Routledge: London, UK, 2000; p. 348.

83. Brito, M. Ciudades Históricas como Destinos Patrimoniales: Una Mirada Comparada: España y Brasil. As Ciudades Históricas como Destinos Patrimoniais: Um Estudo Comparado: Espanha e Brasil; Consejería de Cultura de la Junta de Andalucía: Sevilla, Spain, 2009.

84. Barrera Fernández, D.; Hernández Escampa, M. El impacto de la política urbanística en la gestión de la ciudad histórico-turística: Un estudio comparative. PASOS Rev. Tur. Patrim. Cult. 2016, 14, 705-724. [CrossRef]

85. López Palomeque, F. Barcelona, de ciudad con turismo a ciudad turística. Notas sobre un proceso complejo e inacabado. Doc. D'anàlisi Geogr. 2015, 61, 483-506.

86. Arias, A.; Quaglieri, A. Unravelling Airbnb: Urban perspectives from Barcelona. In Reinventing the Local in Tourism: Producing, Consuming and Negotiating Place; Russo, A.P., Richards, G., Eds.; Channel View Publications: Bristol, UK, 2016 ; pp. $209-228$.

87. Russo, A.P.; Scarnato, A. Barcelona in common: A new urban regime for the 21st-century tourist city? J. Urban Aff. 2018, 40, 455-474. [CrossRef]

88. Blanco-Romero, A.; Blazquez-Salom, M.; Canoves, G. Barcelona, Housing Rent Bubble in a Tourist City. Social Responses and Local Policies. Sustainability 2018, 10, 2043. [CrossRef]

89. Blázquez-Salom, M.; Blanco-Romero, A.; Vera-Rebollo, J.F.; Ivars-Baidal, J. Territorial tourism planning in Spain: From boosterism to tourism degrowth? J. Sustain. Tour. 2019, 27, 1764-1785. [CrossRef]

90. Mendoza-de-Miguel, S.; Ferreiro-Calzada, E.; Calle-Vaquero, M.; de la García Hernández, M. “Overtourism” en centros urbanos. ¿Qué opinan los técnicos de la administración local? In Sostenibilidad Turística: Overtourism vs Undertourism; Pons, G.X., BlancoRomero, A., Navalón-García, R., Troitiño-Torralba, L., Blázquez-Salom, M., Eds.; Monografiesde la Societat d'Història Natural de les Balears: Palma, Spain, 2020; Volume 31, pp. 319-329.

91. Arana García, E. La intervención local en las viviendas de uso turístico a través de la zonificación urbanística: Requisitos y consecuencias. REALA 2018, 10, 6-21. [CrossRef]

92. Román Márquez, A. Planificación urbanística del turismo: La regulación de las viviendas de uso turístico en Madrid y Barcelona. REALA 2018, 10, 22-39. [CrossRef]

93. Fletcher, R.; Murray Mas, I.; Blanco-Romero, A.; Blázquez-Salom, M. Tourism and degrowth: An emerging agenda for research and praxis. J. Sustain. Tour. 2019, 27, 1745-1763. [CrossRef]

94. Higgins-Desbiolles, F.; Carnicelli, S.; Krolikowski, C.; Wijesinghe, G.; Boluk, K. Degrowing tourism: Rethinking tourism. J. Sustain. Tour. 2019, 27, 1926-1944. [CrossRef]

95. Milano, C.; Novelli, M.; Cheer, J.M. Overtourism and degrowth: A social movements perspective. J. Sustain. Tour. 2019, 27, 1857-1875. [CrossRef]

96. Hernández-Martín, R.; Álvarez-Albelo, C.D.; Padrón-Fumero, N. The economics and implications of moratoria on tourism accommodation development as a rejuvenation tool in mature tourism destinations. J. Sustain. Tour. 2015, 23, 881-899. [CrossRef] 
97. Inchausti-Sintes, F.; Voltes-Dorta, A. The economic impact of the tourism moratoria in the Canary Islands 2003-2017. J. Sustain. Tour. 2020, 28, 394-413. [CrossRef]

98. Simancas Cruz, M. La judicialización de las decisiones públicas: El caso de la política de moratoria turística de Canarias. Investig. Tur. 2019, 17, 21-48. [CrossRef]

99. Bertocchi, D.; Camatti, N.; Giove, S.; van der Borg, J. Venice and overtourism: Simulating sustainable development scenarios through a tourism carrying capacity model. Sustainability 2020, 12, 512. [CrossRef]

100. Çakar, K. Developing Sustainable Policies in Response to Overtourism. In Handbook of Research on the Impacts, Challenges, and Policy Responses to Overtourism; Riberio de Almeida, C., Quintano, A., Simancas, M., Huete, R., Breda, Z., Eds.; IGI Global: Hershey, PA, USA, 2020; pp. 1-11.

101. Fistola, R.; La Rocca, R.A. Driving functions for urban sustainability: The double-edged nature of urban tourism. Int. J. Sustain. Dev. Plan. 2017, 12, 425-434. [CrossRef]

102. Veiga, C.; Custódio, M.; Águas, P.; Santos, J.A. Sustainability as a key driver to address challenges. Worldw. Hosp. Tour. Themes 2018, 10, 662-673. [CrossRef]

103. Cocola-Gant, A. Tourism gentrification. In Handbook of Gentrification Studies; Lees, L., Phillips, M., Eds.; Edward Elgar Publishing: Cheltenham, Glos, UK; Northampton, MA, USA, 2018.

104. Amore, A.; Falk, M.; Adie, B.A. One visitor too many: Assessing the degree of overtourism in established European urban destinations. Int. J. Tour. Cities 2020, 6, 117-137. [CrossRef]

105. De la Calle Vaquero, M.; Mendoza-de-Miguel, S.; Ferreiro-Calzada, E.; García Hernández, M. El urbanismo como instrumento de contención de la actividad turística en los centros urbanos: Alcance y limitaciones. In Sostenibilidad Turística: Overtourism vs Undertourism; Pons, G.X., Blanco-Romero, A., Navalón-García, R., Troitiño-Torralba, L., Blázquez-Salom, M., Eds.; Monografiesde la Societat d'Història Natural de les Balears: Palma, Spain, 2020; Volume 31, pp. 121-134. 